\title{
Complex interaction between proliferative kidney disease, water temperature and concurrent nematode infection in brown trout
}

\author{
Heike Schmidt-Posthaus ${ }^{1, *}$, Pascale Steiner ${ }^{2,3}$, Barbara Müller ${ }^{1}$, \\ Ayako Casanova-Nakayama ${ }^{1}$ \\ ${ }^{1}$ Centre for Fish and Wildlife Health, Institute of Animal Pathology, University of Berne, Laenggassstrasse 122, PO Box 8466, \\ 3001 Berne, Switzerland \\ ${ }^{2}$ Federal Office for the Environment FOEN, 3003 Bern, Switzerland \\ ${ }^{3}$ Present address: Ecowert GmbH, Denter Tumas 6, 7013 Domat/Ems, Switzerland
}

\begin{abstract}
Proliferative kidney disease (PKD) is a temperature-dependent disease caused by the myxozoan Tetracapsuloides bryosalmonae. It is an emerging threat to wild brown trout Salmo trutta fario populations in Switzerland. Here we examined (1) how PKD prevalence and pathology in young-of-the-year (YOY) brown trout relate to water temperature, (2) whether wild brown trout can completely recover from $T$. bryosalmonae-induced renal lesions and eliminate $T$. bryosalmonae over the winter months, and (3) whether this rate and/or extent of the recovery is influenced by concurrent infection. A longitudinal field study on a wild brown trout cohort was conducted over 16 mo. YOY and age 1+ fish were sampled from 7 different field sites with various temperature regimes, and monitored for infection with $T$. bryosalmonae and the nematode Raphidascaris acus. T. bryosamonae was detectable in brown trout YOY from all sampling sites, with similar renal pathology, independent of water temperature. During winter months, recovery was mainly influenced by the presence or absence of concurrent infection with $R$. acus larvae. While brown trout without $R$. acus regenerated completely, concurrently infected brown trout showed incomplete recovery, with chronic renal lesions and incomplete translocation of $T$. bryosalmonae from the renal interstitium into the tubular lumen. Water temperature seemed to influence complete excretion of $T$. bryosalmonae, with spores remaining in trout from summer-warm rivers, but absent in trout from summer-cool rivers. In the following summer months, we found PKD infections in 1+ brown trout from all investigated river sites. The pathological lesions indicated a reinfection rather than a proliferation of remaining T. bryosalmonae. However, disease prevalence in $1+$ trout was lower than in YOY.
\end{abstract}

KEY WORDS: Tetracapsuloides bryosalmonae $\cdot \mathrm{PKD} \cdot$ Raphidascaris acus $\cdot$ Water temperature Salmo trutta fario $\cdot$ Pathology $\cdot$ Recovery

Resale or republication not permitted without written consent of the publisher

\section{INTRODUCTION}

The aqueous environment exhibits complex interplay between physical parameters, chemical composition and biological load. Studying host/pathogen interactions in wild fish is one possibility of investigating the influence of environmental factors on the biological balance between fish hosts and infectious agents.

Proliferative kidney disease (PKD) is a temperature-dependent disease which is considered an emerging threat to both wild and cultured salmonid fish in Europe (Okamura et al. 2011). The spread and consequences of the disease are suspected to be 
enhanced by water temperature (Wahli et al. 2008, Bettge et al. 2009, Okamura et al. 2011). The disease is caused by Tetracapsuloides bryosalmonae (Myxozoa: Malacosporea) (Hedrick et al. 1993, Canning et al. 2000, Okamura et al. 2001), with bryozoans as invertebrate hosts (Anderson et al. 1999, Longshaw et al. 1999, Okamura et al. 2001) and salmonids as vertebrate hosts (Feist \& Bucke 1993, Hedrick et al. 1993). T. bryosalmonae infects fish through the skin and gills (Feist et al. 2001, Longshaw et al. 2002). After invasion, this parasite is distributed systemically, with the kidney as the main target organ (Kent \& Hedrick 1985). Here, T. bryosalmonae multiplies and differentiates from extrasporogonic stages, mainly in the renal interstitium, to sporogonic stages in the tubular lumen. In young-of-the-year (YOY), proliferative and granulomatous nephritis and necrotizing vasculitis with thrombus formation are host reactions to parasite infestation (Hedrick et al. 1993, El-Matbouli \& Hoffmann 1994, Bettge et al. 2009). In laboratory studies, we previously showed that surviving fish can recover with complete regeneration of renal morphology (Schmidt-Posthaus et al. 2012). After complete regeneration, no $T$. bryosalmonae spores were detected in surviving rainbow trout by histology or immunohistochemistry (SchmidtPosthaus et al. 2012). However, little is known about regeneration and the possible influencing factors under field conditions in the natural host in Switzerland, the brown trout Salmo trutta fario. In addition, the possible development of disease after recurrent contact with $T$. bryosalmonae in surviving fish in the following year(s) has not yet been studied. Here, we investigated disease development and the location of T. bryosalmonae in brown trout under the influence of varying water temperatures and the presence or absence of a concurrent infection, namely infection with Raphidascaris acus larvae.

Raphidascaris acus is a widely distributed nematode of the digestive tract in predatory fish. Definitive hosts are most frequently pike and brown trout, but other salmonids and occasionally other fish species can also be affected (Smith 1984). The life cycle involves obligate intermediate hosts: various fish species, cyclostomes and gammarids, and rarely also amphibians (Moravec 1970a, 1996, 2004, Smith 1984). In the brown trout, nematodes usually mature in the gut (Smith 1984). Occasionally, third-stage larvae are found in the stomach wall, pyloric caeca, intestine, or liver of young brown trout (Moravec 2004). However, the true relevance of brown trout as intermediate hosts for this nematode is still unclear. The development of $R$. acus is clearly seasonal, depending mainly on water temperature (Moravec 1970b, 1979, 2004). In the intermediate fish hosts, like roach or stone loach, the immune response was described as granuloma or abscess-like lesions containing nematode larvae at different stages of degeneration (Valtonen et al. 1994, Koubková et al. 2004). In brown trout serving as intermediate hosts, the immune response to third-stage larvae has not yet been described in detail.

The aims of our study were to examine: (1) how the PKD prevalence and pathology in YOY brown trout relate to the level and variation of water temperature in the river; (2) whether wild brown trout can completely recover from Tetracapsuloides bryosalmonae-induced renal lesions and eliminate this parasite over the winter months; (3) if this rate and/or extent of the recovery is influenced by concurrent infections, here with Raphidascaris acus; and (4) how disease develops in older fish after recurrent contact to T. bryosalmonae. A longitudinal study on a wild brown trout cohort was conducted over 16 mo. In parallel to detailed measurements of the water temperature in the respective river system, fish were sampled from 7 different river sites at approximately 6, 9, 16 and $18 \mathrm{mo}$ of age and monitored for PKD and R. acus infection, the associated pathology and the location of $T$. bryosalmonae and $R$. acus.

\section{MATERIALS AND METHODS}

\section{Study sites and fish sampling}

The experiments were conducted over a period of 16 mo (June 2008 until September 2009). The river system examined (Lyssbach) is situated in the western midlands of Switzerland and passes through rural and urban areas before feeding into a larger river, the Alte Aare. The Lyssbach has a number of tributaries; 4 of these were included in this study (Allenwilbach, Chuelibach, Seebach and Schmidebach) (Fig. 1). Fish can migrate from the tributaries into the Lyssbach and vice versa. In former years, brown trout Salmo trutta fario were regularly stocked in the Lyssbach, nevertheless electrofishing revealed decreasing numbers of fish along the course of the river (fishing statistics 1993 to 2005, Fishery Inspectorate Bern unpubl. data). Stocked fish originated from wild mother animals from the Lyssbach. Stocking was stopped during the whole experimental period, starting a year before until initiation of the experiment, to be certain a single brown trout generation was investigated originating from the naturally 


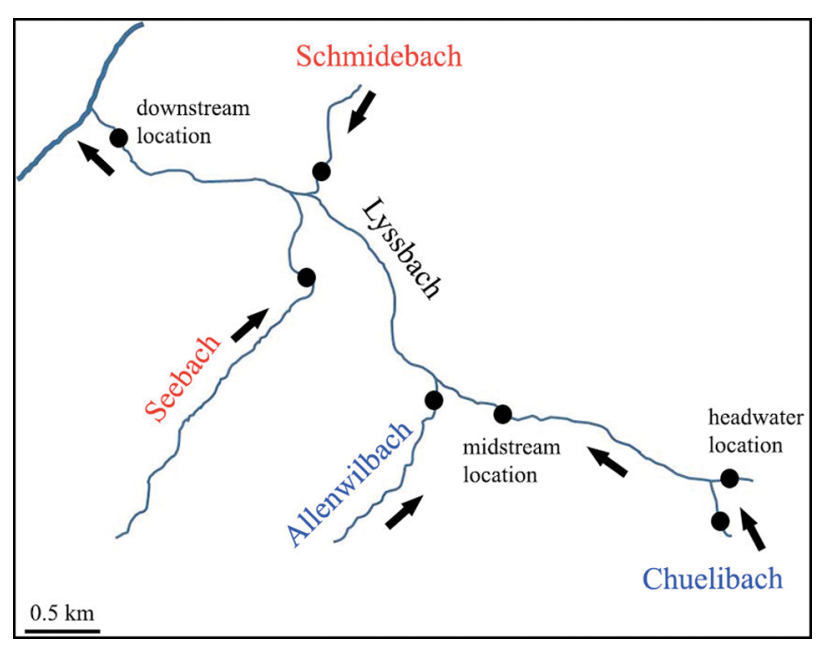

Fig. 1. The Lyssbach and its tributaries flow (black arrows) northwestwards into the Alte Aare near the Swiss city of Bern. The 7 sampling sites are marked by dots. Summercool tributaries (Chuelibach, Allenwilbach) are labelled in blue; summer-warm tributaries (Seebach, Schmidebach) are labelled in red

spawning population in the river. Other susceptible salmonid species do not occur in these river systems. Water temperature was recorded every $10 \mathrm{~min}$ by the Fishery Inspectorate from June 2007 until September 2009 by temperature loggers located in the rivers near the fish sampling sites. Fish were sampled at 3 sites in the Lyssbach River: 1 headwater site, 1 midstream site and 1 downstream site (Fig. 1). Additionally, the 4 tributaries were sampled a few hundred metres to a few kilometres upstream of their entries into the Lyssbach River (Fig. 1). In June 2008, 25 or 26 YOY brown trout were sampled at each of the 3 sites in the Lyssbach, and 60 to 63 brown trout were sampled in each of the 4 tributaries. In September 2008, March and September 2009, 25 and 26 YOY and 1+ brown trout, respectively, were caught at each sampling site by electrofishing. Fish were transported live to the Centre for Fish and Wildlife Health (FIWI), where they were kept in the original river water, supplemented with oxygen, until further examination. This process lasted for a few minutes to a few hours. Single fish were euthanized in buffered 3-aminobenzoic acid ethyl ester (MS 222 ${ }^{\circledR}$, Argent Chemical Laboratories). The length of each individual was measured, immediately followed by a standard necropsy. Fish were examined for changes in external and internal organs. Gills, kidney, liver and intestine were removed, and one gill branch, half of the kidney and the other organs were fixed in 10\% buffered formalin for histopathological and immuno- histochemical (IHC) examination. The other half of the kidney was placed in a separate Eppendorf tube and snap frozen in liquid nitrogen for polymerase chain reaction (PCR) examination.

\section{Histopathology and immunohistochemistry}

Fixed samples were paraffin-embedded and routinely processed for histological and IHC examination; sections of $3 \mu \mathrm{m}$ thickness were cut. For the kidney, 2 consecutive sections were prepared. The first slide was examined histologically. The second slide was used for IHC staining.

Sections for histology were stained with haematoxylin-eosin (H\&E) and examined by light microscopy. Histopathological changes of the gills, kidney, liver and intestine were graded as 0 (none), 1 (scattered), 2 (mild), 3 (mild to moderate), 4 (moderate), 5 (moderate to severe), or 6 (severe). The presence of Raphidascaris acus and Tetracapsuloides bryosalmonae was determined on histological sections of kidney, liver and intestine.

IHC staining to detect the presence of the Tetracapsuloides bryosalmonae antigen using a monoclonal anti-T. bryosalmonae (PKX) antibody (Aqua MAb-P01, Aquatic Diagnostics) was performed according to the protocol of Adams et al. (1992).

\section{PCR for detection of Tetracapsuloides bryosalmonae DNA in kidney tissue}

Fish negative for Tetracapsuloides bryosalmonae by histology and/or IHC were examined by PCR. Total DNA of rainbow trout kidneys was extracted from approximately 50 to $100 \mathrm{mg}$ of frozen kidney tissue of each examined fish with DNAzol (Lucerna) according to the manufacturer's protocol. The extracted DNA was resuspended in $8 \mathrm{mM} \mathrm{NaOH}$ and stored at $4^{\circ} \mathrm{C}$. The yield was determined by spectrophotometry using the NanoDrop photometer (NanoDrop Technologies). PCR was performed according to the protocol by Morris et al. (2002), with some modifications. The primer pair PKX3F (CTA AGT ACA TAC TTC GGT AGA) and PKX4R (CCG TTA CAA CCT TGT TAG GAA), described by Kent et al. (1998), was used. A positive control sample obtained from kidney of clinically infected brown trout and a negative control of uninfected kidney obtained from farmed fish with no history of $T$. bryosalmonae infection were included in the PCR procedure. 


\section{PCR and sequencing for confirmation of Raphidascaris acus larvae in the intestinal wall and body cavity}

To confirm the nematode species found histologically in the lesions in the intestine, perivisceral fat tissue and liver, 5 severely affected fish were selected. The intestine and pieces of the perivisceral fat tissue, including the nematode larvae, were cut out, and five $20 \mu \mathrm{m}$ sections were deparaffinised. Lysis and DNA extraction were performed with the DNeasy tissue kit (Qiagen) according to the manufacture's protocol. The extracted DNA was resuspended in $8 \mathrm{mM} \mathrm{NaOH}$ and stored at $4^{\circ} \mathrm{C}$. The yield was determined by spectrophotometry using the NanoDrop photometer. PCR was performed with a HotStarTaq Kit (Qiagen) according to the manufacturer's protocol. Forward and reverse primers $(R$. acus fwd AGA AGA TGC GCT TCA CGA T, $R$. acus rev ACC ATA TGC TCG CCG AAT AC) were designed to amplify a 297 base-pair region of the selected 5.8S rDNA sequence of $R$. acus (GenBank Accession No. AY603537). As a negative control, the liver, spleen and kidney tissues of uninfected farmed fish were included. To confirm the specificity of the PCR, PCR products were transformed into pGEM ${ }^{\circledR}$-T Easy vector systems (Promega) and DH5 $\alpha$-competent cells as described in the manufacture's protocol. The following sequencing was performed by ABI PRISM using the T7 primer.

\section{Statistical analysis}

PKD and Raphidascaris acus infection prevalence were calculated by the sum of Tetracapsuloides bryosalmonae- or $R$. acus-positive individuals per group, respectively, divided by the total number of individuals per group. Results were tested for normal distribution with the skewness, kurtosis and omnibus normality tests, and then were compared and tested for significant differences using a 1-way ANOVA with a $\mathrm{p} \leq 0.05$ significance level. For statistical tests, NCSS 2001 (Hintze 2006) was used.

\section{RESULTS}

\section{Water temperature}

During the summer months, water temperatures of $15^{\circ} \mathrm{C}$ and higher, known to be critical for the development of severe clinical signs of PKD and mortality, were reached for a couple of weeks at all but one location (Chuelibach) (Fig. 2). In the Chuelibach, day temperature exceeded $15^{\circ} \mathrm{C}$ only twice during July 2009. In the Lyssbach, from 2007 to 2009 , water temperature reached $15^{\circ} \mathrm{C}$ and higher for 56 to $71 \mathrm{~d}$ at the headwater location, for 20 to $42 \mathrm{~d}$ at the midstream location and for 70 to $96 \mathrm{~d}$ at the downstream location (Fig. 2). Therefore, the duration of warm-water temperatures was longest at the downstream location and shortest at the midstream location. In the 2 warmer tributaries (Seebach and Schmidebach), water temperatures $\geq 15^{\circ} \mathrm{C}$ were reached for up to $70 \mathrm{~d}$ in the Seebach and for up to $98 \mathrm{~d}$ in the Schmidebach. In contrast, in the Allenwilbach, $15^{\circ} \mathrm{C}$ and higher were only measured 23 to $48 \mathrm{~d} \mathrm{yr}^{-1}$. Therefore, roughly 3 categories could be formed: (1) the Chuelibach, rarely exceeding $15^{\circ} \mathrm{C}$ water temperature, (2) Allenwilbach and Lyssbach, midstream location, with $<50$ warm water days and (3) Seebach, Schmidebach and Lyssbach, headwater and downstream locations, with over $50 \mathrm{~d}$ warmer than $15^{\circ} \mathrm{C}$ water temperature. The tributaries could be divided into: (i) summer-cool tributaries (Chuelibach and Allenwilbach) and (ii) summer-warm tributaries (Seebach and Schmidebach) (Fig. 2).

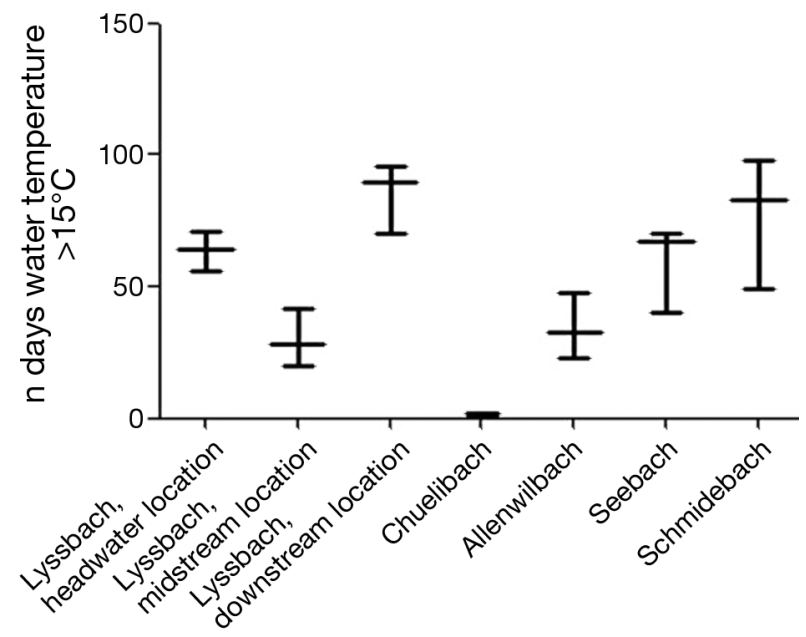

Fig. 2. Number of days with water temperature exceeding $15^{\circ} \mathrm{C}$ (known to be critical for the development of severe clinical signs of proliferative kidney disease [PKD] and PKDrelated mortality) at different sampling sites; shown are total number of days in 2007, 2008, and 2009 as a mean value (horizontal line) and as lowest and highest values (error bars). There are 3 categories visible: (1) the Chuelibach, rarely exceeding $15^{\circ} \mathrm{C}$ water temperature; (2) Allenwilbach and Lyssbach, midstream location, with $<50$ warm-water days; and (3) Seebach, Schmidebach and Lyssbach, headwater and downstream locations, with $>50 \mathrm{~d}$ warmer than $15^{\circ} \mathrm{C}$ water temperature 


\section{Infection prevalence}

\section{Raphidascaris acus}

Identification of Raphidascaris acus larvae was based on typical appearance in histological sections (Valtonen et al. 1994, Koubková et al. 2004). The nematode larvae consist of a cuticle with lateral alae and lateral pores, a muscle layer and a digestive tract (Fig. 3). In addition, samples examined by PCR and sequencing showed a 95\% similarity with $R$. acus.

Raphidascaris acus larvae were only found in the Lyssbach, with one exception: one infected trout was found in the Seebach in September 2009. In the Lyssbach, infections with $R$. acus larvae were found in all 3 locations, beginning in September 2008, with the highest prevalences in age 1+ fish in March and September 2009 (Table 1). A prevalence as high as 88\% at the midstream location in the Lyssbach was found in September 2009. Apart from a single animal from the downstream location in the Lyssbach which tested negative for Tetracapsuloides bryosalmonae by PCR, all brown trout Salmo trutta fario positive for $R$. acus were found to be positive for $T$. bryosalmonae as well.

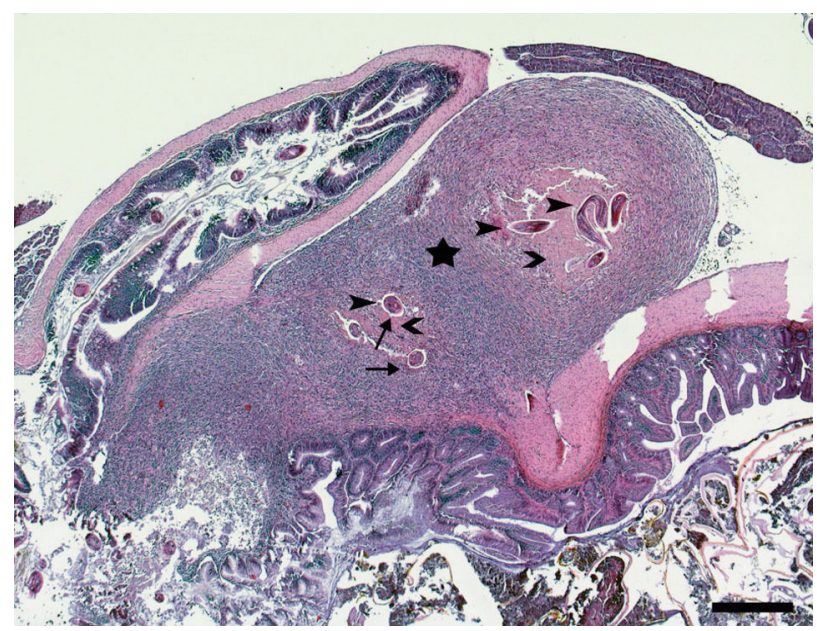

Fig. 3. Raphidascaris acus larvae in the intestinal wall of age 1+ brown trout Salmo trutta fario from Lyssbach, midstream location, March 2009. Histological changes and parasite localization. Transmural infiltration (star) extending to surrounding fat tissue with macrophages and a rim of fibroblasts and eosinophilic granular cells. In the centre of this granulomatous infiltration, cell and nuclear debris (necrosis) can be seen (open arrowheads) and several cut sections of nematode larvae (arrowheads). The nematode larvae consist of a cuticle with lateral alae (arrows) and lateral pores, a muscle layer and a digestive tract. H\&E stain. Scale bar $=50 \mu \mathrm{m}$

\section{Tetracapsuloides bryosalmonae}

In June 2008, Tetracapsuloides bryosalmonae was found by histology and IHC only in single YOY from all sampling sites, excluding the Lyssbach midstream site. These parasites were not associated with any pathological lesions. However, with PCR, T. bryosalmonaepositive fish were already found in all sampling sites, with prevalences between 20 and 50\% (Table 1). In September of the same year, the prevalence of $T$. bryosalmonae-positive YOY increased up to $100 \%$ in most sampling sites (measured by histology, immunohistochemistry and PCR), except Chuelibach and Seebach, where prevalences remained <60\% (Table 1). PKD prevalences at these 2 sites differed significantly from those at the other sites $(p<0.001)$. Whereas in the Chuelibach, water temperature exceeded $15^{\circ} \mathrm{C}$ only twice (summer-cool tributary), in the Seebach, water temperature was $>15^{\circ} \mathrm{C}$ for $70 \mathrm{~d}$ in 2008 (summerwarm tributary). In March 2009, parasitic DNA was still present in 88 to $96 \%$ of investigated fish in the Lyssbach, at all 3 locations, and in the Seebach. In these locations, T. bryosalmonae were also visible by histology or IHC. At this time point, fish in the Lyssbach were concurrently infected with nematode larvae. In contrast, in the Allenwilbach and Chuelibach, T. bryosalmonae DNA was only detectable in 8 or $12 \%$ of trout, respectively (Table 1), and no parasites were detectable by histology or IHC, either intact or degraded. The Allenwilbach and Chuelibach belong to the summer-cool tributaries. In September 2009, in age 1+ trout, $T$. bryosalmonae DNA was detectable in 64 to $100 \%$ of brown trout in all locations of the Lyssbach, the Seebach and the Chuelibach. In the Allenwilbach, only $20 \%$ of the investigated fish tested positive for $T$. bryosalmonae DNA. However, by histology and IHC, in the Lyssbach, only 16 (headwater location), 28 (midstream location) and $40 \%$ (downstream location) of investigated fish showed T. bryosalmonae in their tissues. Of the brown trout originating from the Seebach, $16 \%$ showed these parasites in their renal tissue. In the summer-cool tributaries, Allenwilbach and Chuelibach, none or only $4 \%$ of the fish were revealed to be positive by IHC, respectively.

\section{Pathology and parasite location}

Intestinal and liver pathology associated with Raphidascaris acus infection

In all affected fish, infection with Raphidascaris acus larvae was associated with a transmural granu- 
Table 1. Tetracapsuloides bryosalmonae (T.b.) and Raphidascaris acus (R.a.) in wild brown trout Salmo trutta fario from Lyssbach (headwater, midstream and downstream locations), Chuelibach, Allenwilbach, Seebach and Schmidebach. Number of fish examined per site $(\mathrm{N})$, prevalence of $R$. acus infections (measured by histology), of $T$. bryosalmonae infections (measured by histology, immunohistochemistry and PCR) and of histological renal lesions induced by the T. bryosalmonae infection. Renal pathology (score and morphologic appearance) and location of $T$. bryosalmonae in the kidney are also shown. The pathology score is a mean, with the highest and lowest values in parentheses. h.n.v.: histologically not visible

\begin{tabular}{|c|c|c|c|c|c|c|c|c|}
\hline \multirow[t]{2}{*}{ Age } & \multirow[t]{2}{*}{ Month } & \multirow[t]{2}{*}{$\mathrm{N}$} & \multicolumn{3}{|c|}{ Prevalence (\%) of: } & \multicolumn{2}{|c|}{ Renal pathology due to T.b. infection: } & \multirow[t]{2}{*}{ Location of T.b. } \\
\hline & & & R.a. & T.b. & $\begin{array}{c}\text { Renal changes } \\
\text { due to T.b. } \\
\text { infection }\end{array}$ & Score & Morphology & \\
\hline \multicolumn{9}{|c|}{ Lyssbach } \\
\hline \multicolumn{9}{|c|}{ Headwater location } \\
\hline $0+$ & Jun & 26 & 0 & 50 & 0 & $0(0,0)$ & h.n.v. & h.n.v. \\
\hline $0+$ & Sep & 25 & 20 & 100 & 96 & $3.56(0,6)$ & $\begin{array}{l}\text { Granulomatous and necrotizing } \\
\text { nephritis and vasculitis with } \\
\text { thrombus formation }\end{array}$ & $\begin{array}{l}\text { Gill capillaries, renal inter- } \\
\text { stitium and vessels }\end{array}$ \\
\hline $1+$ & Mar & 26 & 69 & 96 & 69 & $1.19(0,4)$ & $\begin{array}{l}\text { Granulomatous nephritis with } \\
\text { fibrosis }\end{array}$ & $\begin{array}{l}\text { Renal interstitium and } \\
\text { tubular lumen }\end{array}$ \\
\hline $1+$ & Sep & 25 & 40 & 100 & 16 & $0.72(0,6)$ & $\begin{array}{l}\text { Granulomatous and necrotizing } \\
\text { nephritis and vasculitis with } \\
\text { thrombus formation }\end{array}$ & $\begin{array}{l}\text { Renal interstitium and } \\
\text { vessels }\end{array}$ \\
\hline \multicolumn{9}{|c|}{ Midstream location } \\
\hline $0+$ & Jun & 25 & 0 & 43 & 0 & $0(0,0)$ & h.n.v. & h.n.v. \\
\hline $0+$ & Sep & 25 & 12 & 100 & 96 & $4.24(0,6)$ & $\begin{array}{l}\text { Granulomatous and necrotizing } \\
\text { nephritis and vasculitis with } \\
\text { thrombus formation }\end{array}$ & $\begin{array}{l}\text { Gill capillaries, renal inter- } \\
\text { stitium and vessels }\end{array}$ \\
\hline $1+$ & Mar & 25 & 52 & 92 & 60 & $1.36(0,5)$ & $\begin{array}{l}\text { Granulomatous nephritis with } \\
\text { fibrosis }\end{array}$ & $\begin{array}{l}\text { Renal interstitium and } \\
\text { tubular lumen }\end{array}$ \\
\hline $1+$ & Sep & 25 & 88 & 100 & 24 & $0.76(0,6)$ & $\begin{array}{l}\text { Granulomatous and necrotizing } \\
\text { nephritis and vasculitis with } \\
\text { thrombus formation }\end{array}$ & $\begin{array}{l}\text { Renal interstitium and } \\
\text { vessels }\end{array}$ \\
\hline \multicolumn{9}{|c|}{ Downstream location } \\
\hline $0+$ & Jun & 25 & 8 & 50 & 0 & $0(0,0)$ & h.n.v. & h.n.v. \\
\hline $0+$ & Sep & 25 & 0 & 100 & 100 & $5.04(0,6)$ & $\begin{array}{l}\text { Granulomatous and necrotizing } \\
\text { nephritis and vasculitis with } \\
\text { thrombus formation }\end{array}$ & $\begin{array}{l}\text { Gill capillaries, renal inter- } \\
\text { stitium and vessels }\end{array}$ \\
\hline $1+$ & Mar & 26 & 54 & 69 & 38 & $0.6(0,3)$ & $\begin{array}{l}\text { Granulomatous nephritis with } \\
\text { fibrosis }\end{array}$ & $\begin{array}{l}\text { Renal interstitium and } \\
\text { tubular lumen }\end{array}$ \\
\hline $1+$ & Sep & 25 & 32 & 92 & 40 & $3.57(0,5)$ & $\begin{array}{l}\text { Granulomatous and necrotizing } \\
\text { nephritis and vasculitis with } \\
\text { thrombus formation }\end{array}$ & $\begin{array}{l}\text { Gill capillaries, renal inter- } \\
\text { stitium and vessels }\end{array}$ \\
\hline \multicolumn{9}{|c|}{ Chuelibach } \\
\hline $0+$ & Jun & 61 & 0 & 18 & 0 & $0(0,0)$ & h.n.v. & h.n.v. \\
\hline $0+$ & Sep & 25 & 0 & 44 & 8 & $0.28(0,4)$ & $\begin{array}{l}\text { Granulomatous and necrotizing } \\
\text { nephritis and vasculitis with } \\
\text { thrombus formation }\end{array}$ & $\begin{array}{l}\text { Renal interstitium and } \\
\text { vessels }\end{array}$ \\
\hline $1+$ & Mar & 25 & 0 & 12 & 0 & $0(0,0)$ & h.n.v. & h.n.v. \\
\hline $1+$ & Sep & 25 & 0 & 64 & 4 & $0.17(0,4)$ & $\begin{array}{l}\text { Granulomatous and necrotizing } \\
\text { nephritis and vasculitis with } \\
\text { thrombus formation }\end{array}$ & $\begin{array}{l}\text { Renal interstitium and } \\
\text { vessels }\end{array}$ \\
\hline \multicolumn{9}{|c|}{ Allenwilbach } \\
\hline $0+$ & Jun & 63 & 0 & 18 & 0 & $0(0,0)$ & h.n.v. & Occasionally vessels \\
\hline $0+$ & Sep & 25 & 0 & 100 & 88 & $3.92(0,6)$ & $\begin{array}{l}\text { Granulomatous and necrotizing } \\
\text { nephritis and vasculitis with } \\
\text { thrombus formation }\end{array}$ & $\begin{array}{l}\text { Gill capillaries, renal inter- } \\
\text { stitium and vessels }\end{array}$ \\
\hline $1+$ & Mar & 26 & 0 & 8 & 0 & $0(0,0)$ & h.n.v. & h.n.v. \\
\hline $1+$ & Sep & 25 & 0 & 20 & 0 & $0(0,0)$ & h.n.v. & h.n.v. \\
\hline
\end{tabular}


Table 1 (continued)

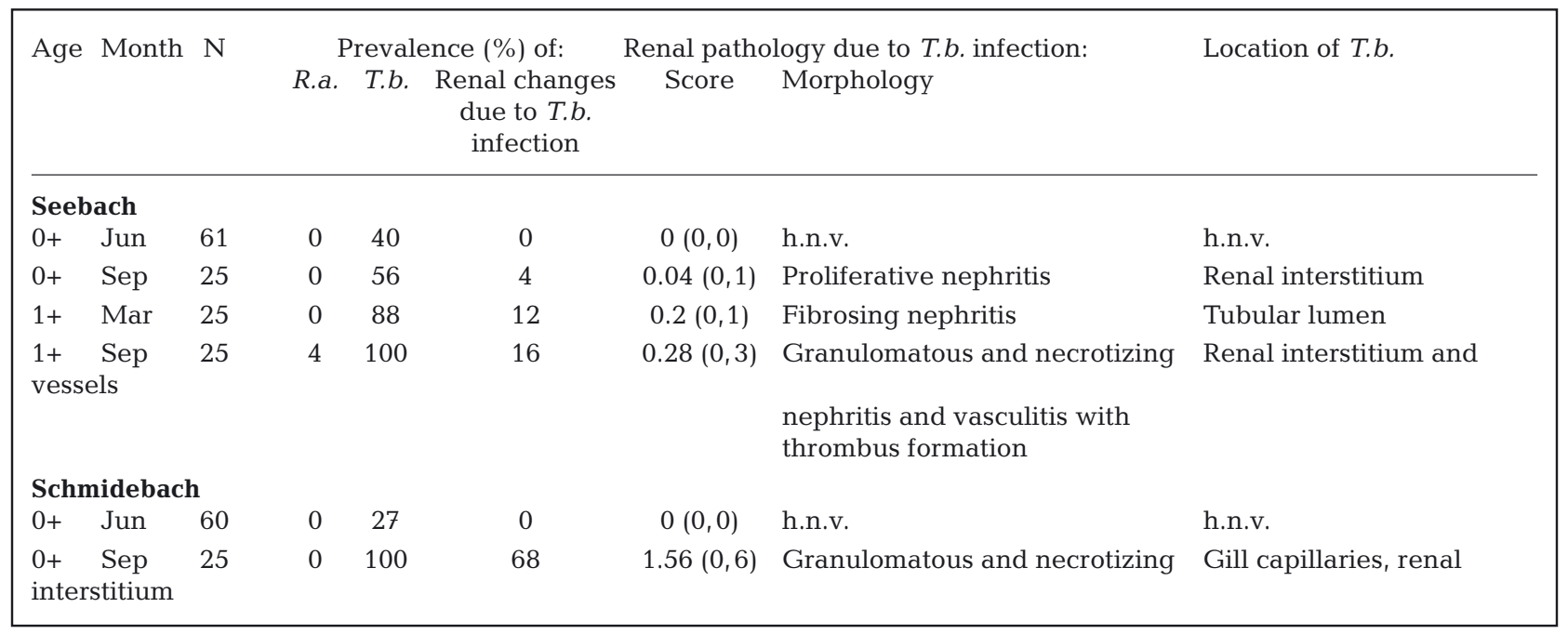

lomatous enteritis and intestinal perforation, often leading to granulomatous peritonitis (Fig. 3). In March 2009, at the midstream location in the Lyssbach, there were 2 fish with migrating larvae reaching the liver accompanied by a granulomatous hepatitis with intralesional larvae.

Kidney pathology associated with Tetracapsuloides bryosalmonae infection and location of parasites

In June of the first year, in YOY, infestations were not associated with any histopathological lesions in the kidney or any other examined organ (Table 1). In September, in the same age class, infection with Tetracapsuloides bryosalmonae was mostly associated with severe lesions, mainly in the kidney, characterized by proliferation of the interstitial tissue, granulomatous inflammation, multiple areas of necrosis and haemorrhage, necrotising vasculitis and thrombus formation (Fig. 4, Table 1). Pathology scores of histological lesions induced by the $T$. bryosalmonae infection are listed in Table 1. In the affected renal areas moderate to high amounts of parasites with secondary and tertiary cells were visible. In several animals, granulomatous changes were also present in the gills, liver, intestine and/or fat tissue. These changes were independent of water temperature. In March of the following year, in age 1+ trout, kidney morphology was restored in all individuals originating from the tributaries, with an increased number of newly formed tubuli, characterized by a small amount of dark basophilic cytoplasm, large oval nuclei and

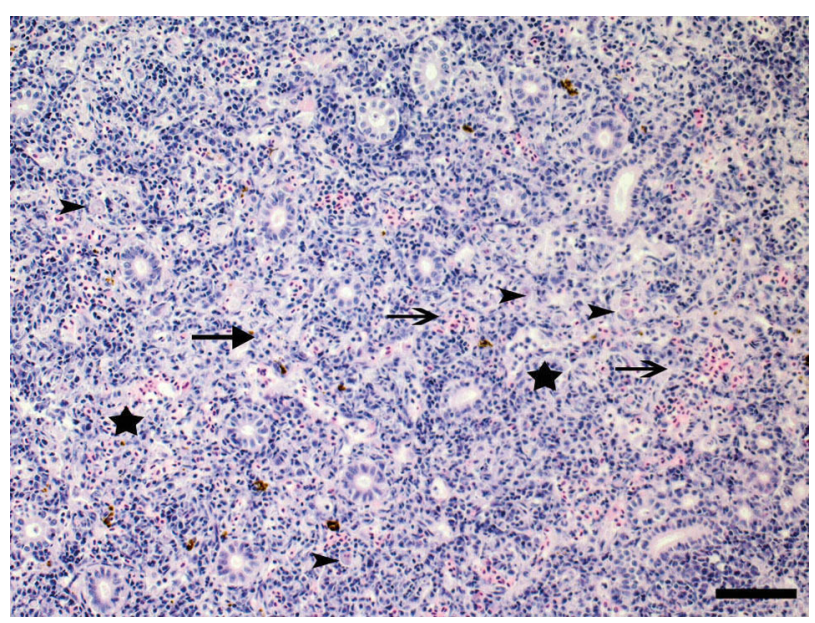

Fig. 4. Tetracapsuloides bryosalmonae in the kidney of YOY brown trout Salmo trutta fario from Lyssbach, midstream location, September 2008. The kidney interstitium is severely expanded by infiltration with mainly macrophages (stars), necrotic cell debris, haemorrhage (thin arrows) and $T$. bryosalmonae parasites (arrowheads). Renal blood vessel with multiple thrombi consisting of inflammatory cells (macrophages, lymphocytes and plasma cells), often degenerated, cell debris and parasites (thick arrow). H\&E stain. Scale bar $=50 \mu \mathrm{m}$

increased numbers of mitotic figures, and developing glomeruli, especially in fish originating from the Seebach (Fig. 5a, Table 1). In the Seebach, IHC-positive parasites were only present in the tubular lumen (Fig. 5b). In fish originating from the Allenwilbach or Chuelibach (summer-cool tributaries), no $T$. bryosalmonae were visible, either in the interstitium or in the tubular lumen. Fish originating from the Lyssbach, which concurrently harboured 

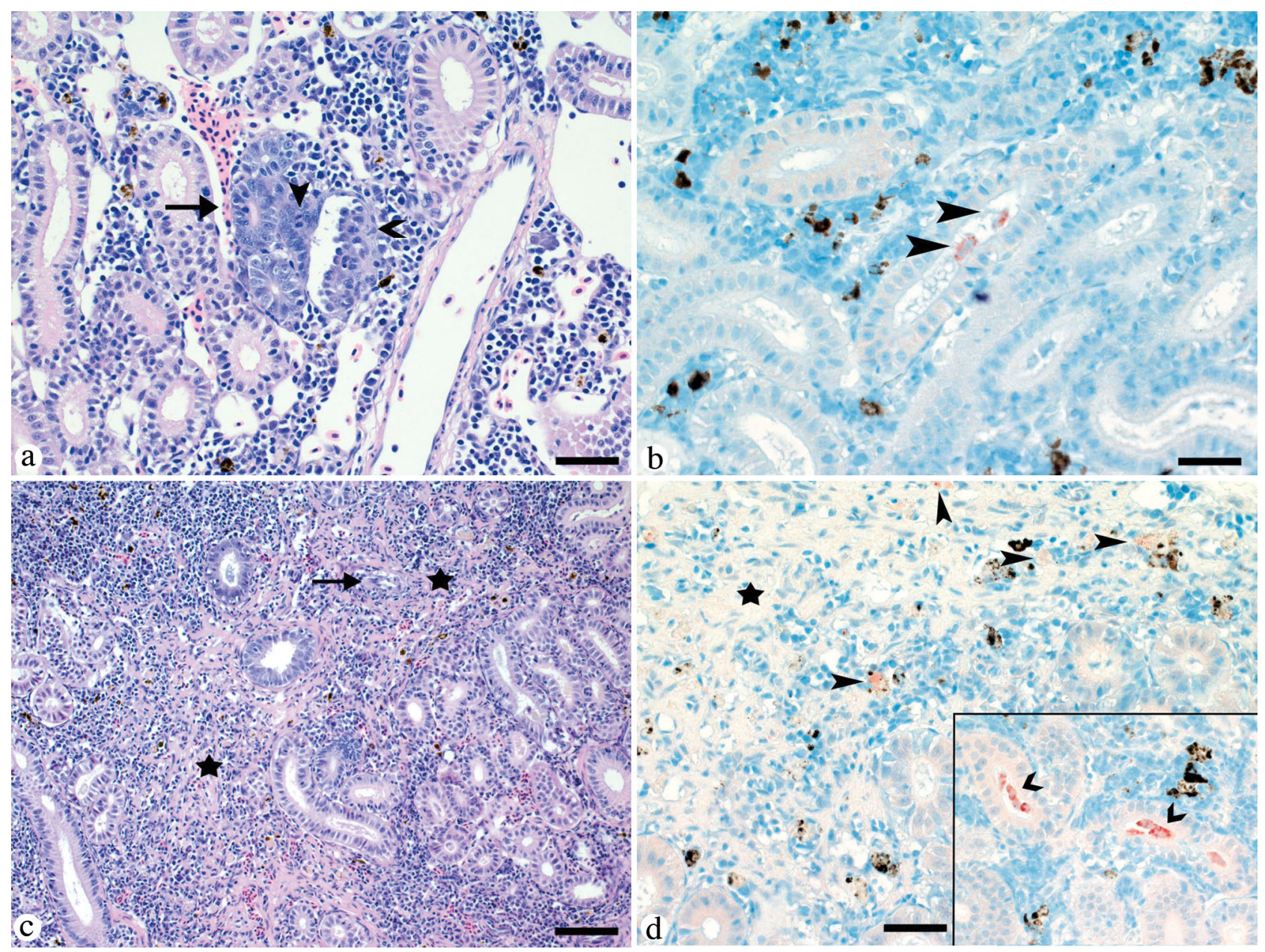

Fig. 5. Tetracapsuloides bryosalmonae in the kidneys of age 1+ brown trout Salmo trutta fario, March 2009. Histological changes and parasite localization in fish from Seebach (a,b) and from Lyssbach, downstream location (c,d). (a) Seebach, H\&E stain; renal morphology is restored, beside an increase in immature tubuli (arrow) with increased numbers of mitotic figures (arrowhead) and immature glomeruli (open arrowhead). (b) Immunohistochemistry; intact sporogonic forms of T. brosalmonae are exclusively located in the tubular lumen (arrowheads). (c) Lyssbach, H\&E stain; kidney interstitium is expanded by fibrosis (stars), multiple tubuli show signs of degeneration (tubulonephrosis) (arrow). (d) Immunohistochemistry; parasites are located in interstitium, mainly degenerated (arrowheads), and tubular lumen (insert, open arrowheads) interstitium is expanded by fibrosis (star). H\&E stain. Scale bars $=25 \mu \mathrm{m}(\mathrm{a}, \mathrm{b})$ and $50 \mu \mathrm{m}(\mathrm{c}, \mathrm{d})$

Raphidascaris acus larvae, showed chronic renal changes, as interstitial fibrosis, mild to moderate macrophage infiltration and tubulonephrosis (Fig. 5c, Table 1). Using immunohistochemistry, $T$. bryosalmonae were present in the interstitial tissue, often showing signs of degeneration (hypereosinophilia and fragmentation of parasite cells and nuclei), and in the tubular lumen (Fig. 5d, insert). Parasites in the tubular lumen were morphologically intact. In September, in age $1+$ trout, $T$. bryosalmonae DNA was found in a high percentage of individuals. However, many fewer individuals showed histological lesions associated with histologically visible parasites. In the Lyssbach, lesions were obvious in only 16 to $40 \%$ of fish, with a clear increase from the upstream $(16 \%)$ to the downstream sampling site $(40 \%)$. In the tributaries, $16 \%$ of investigated trout in the Seebach showed histological lesions. Only $4 \%$ of fish in the Chuelibach and none of the investigated trout originating from the Allenwilbach showed any PKD lesions. The Chuelibach and Allenwilbach were classified as summer-cool tributaries. Histological lesions in the age $1+$ trout were similar to the ones seen in YOY, like granulomatous and necrotising nephritis and vasculitis with thrombus formation (Fig. 6a,b). In addition, in several animals, parasites were seen in the gill lamellae and filaments (Fig. 6c). 


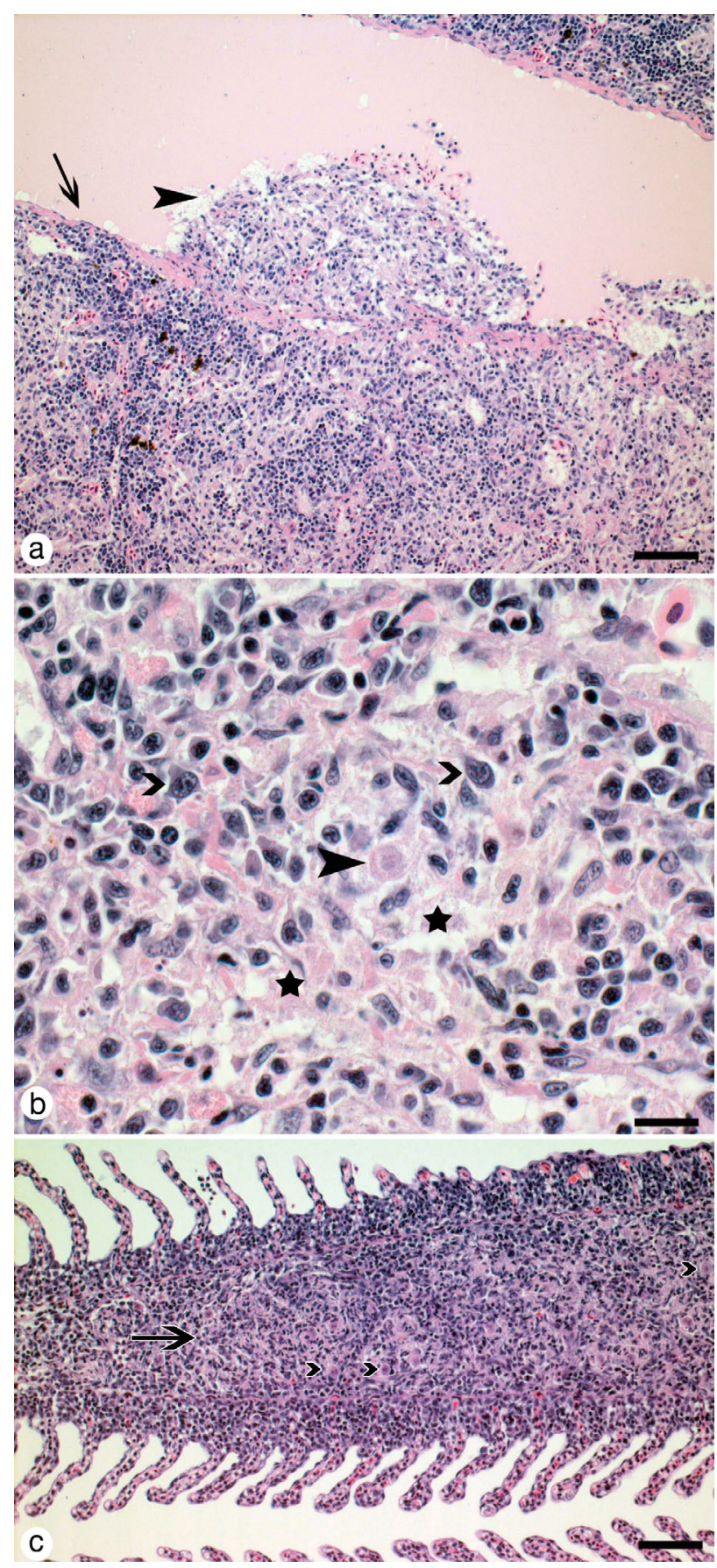

Fig. 6. Tetracapsuloides bryosalmonae in the kidneys and gill of age 1+ brown trout Salmo trutta fario, September 2009. Histological changes and parasite localization in fish from Lyssbach, downstream location (a to c). (a) Kidney; multiple vessels (arrow) are filled with thrombi (arrowhead), composed of inflammatory cells, fibrin and parasites. (b) Renal interstitium is expanded by fibrin, necrotic cell debris (stars), macrophages (open arrowheads) and parasites (arrowhead). (c) Gill, filament is expanded (arrow) by infiltration with macrophages and lymphocytes, and high numbers of parasites (open arrowheads). H\&E stain. Scale bars = $50 \mu \mathrm{m}(\mathrm{a}, \mathrm{c})$ and $25 \mu \mathrm{m}(\mathrm{b})$

\section{DISCUSSION}

We have shown in previous experimental studies that PKD prevalence and the associated pathology is only slightly influenced by water temperature in rainbow trout YOY (Schmidt-Posthaus et al. 2012). In the present study, we investigated the influence of water temperature on the disease under natural conditions in brown trout Salmo trutta fario. Comparable to the laboratory study, Tetracapsuloides bryosamonae was detectable in YOY brown trout from all sampling sites, independent of river water temperature during summer months. In most sites, almost $100 \%$ of the investigated fish were infected with $T$. bryosalmonae. However, in 2 river sites, the Seebach and Chuelibach, PKD prevalence was significantly lower than in other sampling sites. The reason for this remains unclear as these 2 rivers showed different water temperature regimes, with the Seebach being classified as a summer-warm and the Chuelibach as a summer-cool river. A different infection pressure could be a possible reason for this phenomenon. However, measurements of spore concentrations under field conditions are difficult. Fish that developed clinical signs showed the same histological renal lesions at all sampling sites. Therefore, comparable to our results gained from experimental studies, PKD prevalence and the composition of pathological lesions in infected YOY were not associated with water temperature. It has previously been shown that rainbow trout surviving the clinical phase of PKD are able to completely regenerate renal morphology and that this process is not influenced by water temperature (Ferguson 1981, Kent \& Hedrick 1985, Clifton-Hadley et al. 1987, Schmidt-Posthaus et al. 2012). In accordance with these findings, in our study fish from all tributaries, independent of summer-warm or summercool water, renal morphology could be completely restored during the winter months. Fish are capable of regenerating renal tissue by repopulation of injured nephrons and, unlike mammals, by the de novo production of nephrons. Renal regeneration by nephron neogenesis has been reported in catfish, rainbow trout, tomcod, zebrafish, tilapia, aglomerular toadfish and medaka (Reimschuessel et al. 1990, 1996, Reimschuessel 2001, Salice et al. 2001, Watanabe et al. 2009, Diep et al. 2011). In contrast to fish from the tributaries, 38 to $69 \%$ of brown trout originating from the Lyssbach still showed chronic renal changes in March 2009 as age 1+ fish, together with, mainly degenerated, intralesional $T$. bryosalmonae. Therefore, a considerably high percentage of individuals from these locations was not able to completely 
recover during the winter months and eliminate these parasites. These fish were concurrently infected with Raphidascaris acus larvae, leading to severe granulomatous lesions in different inner organs, like the intestinal wall, pyloric caeca, perivisceral fat tissue and liver. Therefore, the recovery process following a PKD infection seemed to be influenced by the concurrent parasitic disease. The fish immune response against myxozoan infections in general consists of cellular components, like macrophages, lymphocytes, and granulocytes, and of humoral components, like lysozyme, peroxidases, complement pathways and specific antibodies (Sitjà-Bobadilla 2008). It is possible that this immune response is influenced and possibly retarded by the concurrent infection. A synergistic effect of 2 concurrent infections is also described for e.g. tilapia and catfish concurrently infected with Myxobolus tilapiae and Flavobacterium columnare (Eissa et al. 2010). In mammals it has previously been shown that co-infection with different parasites can polarize the T-cell response in susceptible hosts (Zeidner et al. 2000). The exact mechanisms for this polarization are still unknown.

The location of Tetracapsuloides bryosalmonae in surviving brown trout during spring also seems to be dependent on water temperature and/or concurrent infection. Whereas fish from the summer-cool tributaries no longer showed $T$. bryosalmnae detectable by IHC in March 2009, in trout originating from the Seebach, these parasites were still present in the tubular lumen. Therefore, translocation in the tubular lumen was obvious, but spore elimination until spring was only seen in the summer-cool tributaries. In a recent experimental study dealing with rainbow trout, we showed that as soon as $103 \mathrm{~d}$ post-infection no $T$. bryosalmonae were visible by IHC, independent of water temperature (Schmidt-Posthaus et al. 2012). However, translocation into the tubular lumen was not obvious in the latter study, as elimination of $T$. bryosalmonae seemed rather to be taking place through degeneration of the parasites in the interstitium than by translocation into the tubular lumen (Bettge et al. 2009, Schmidt-Posthaus et al. 2012). These species differences were also shown by Morris \& Adams (2006) and Grabner \& El-Matbouli (2008), who were only able to demonstrate excreted spores in brown Salmo trutta and brook trout Salvelinus fontinalis, but not in rainbow trout. Similar to our results in rainbow trout, showing degenerated $T$. bryosalmonae in the renal interstitium, brown trout originating from the Lyssbach also showed IHC-positive, mainly degenerated, $T$. bryosalmonae in the renal interstitium of age 1+ individuals. Therefore, these fish were not able to translocate $T$. bryosalmonae completely into tubuli. Concurrent infection with Raphidascaris acus and the associated lesions may have led to a decreased ability to translocate $T$. bryosalmonae. To test this hypothesis further studies including investigations of the immune response are necessary.

By PCR, Tetracapsuloides bryosalmonae DNA was detectable over the whole study period. This is in accordance with our laboratory studies, in which parasite DNA was also detectable until the end of the experimental study (Schmidt-Posthaus et al. 2012). Whether detectable $T$. bryosalmone DNA is consistent with latent parasites, which could be reactivated, or just genomic remnants, which are biologically inactive, remains unclear.

In this study, we showed PKD infection in age 1+ brown trout from all investigated river sites in September 2009. The pathological lesions, like acute gill and kidney lesions, indicate re-infection rather than proliferation of the remaining parasites. However, while Tetracapsuloides bryosalmonae DNA was detectable in a great number of fish, prevalence of histological lesions in age 1+ fish was lower than that in YOY fish. Especially in brown trout originating from the summer-cool tributaries, histological renal lesions were limited to single individuals. Therefore, surviving fish were in contact with $T$. bryosalmonae in the following year, but clinical disease was evident in only a small percentage, indicating at least partimmunity. Protective immunity has been recorded for other myxozoan parasites like Myxobolus cerebralis (Hedrick et al. 1998) and Enteromyxum scophthalmi (Sitjà-Bobadilla et al. 2007). In this study, the reinfection rate with $T$. bryosamonae and associated lesions seemed to be influenced again by water temperature and concurrent infection. In brown trout originating from the Lyssbach and the Seebach, lesions were more prominent compared to those in brown trout from Chuelibach and Allenwilbach. The complex interactions between the different infectious agents and the factors leading to disease outbreaks and the associated severe pathology with Raphidascaris acus larvae infestation remain to be investigated. It is still unclear why PKD and $R$. acus infestations interact and provoke severe tissue reactions in brown trout from the Lyssbach but not in the tributaries. One possible explanation might be other influencing environmental factors, like pollution by agricultural runoffs. Another factor which could influence the re-infection rate and associated lesions in 1+ fish might be the $T$. bryosalmonae actinospore density and possible differences between the sam- 
pling sites. However, reliable measurements of actinospore density in the water are not possible to date. Further investigations of this aspect would improve our understanding of the driving factors of PKD disease in older brown trout.

This study is an example showing the complex interactions between host-pathogen and environmental conditions. We showed that water temperatures not only influence individual species, but also host-pathogen interactions, which can, in the end, catalyze population declines (e.g. Karvonen et al. 2010, Johnson \& Paull 2011).

Acknowledgements. The study was financially supported by the Federal Office for the Environment (FOEN), Bern, Switzerland, and the Fishery Authorities of the Canton of Bern, Bern, Switzerland. Thanks are due to the Fishery Authorities of the Canton of Bern for providing the temperature data. We also thank Jörg Ramseier for providing the fish for analysis. We thank our colleagues from the FIWI for their help during the samplings, the staff of the histology laboratory of the Institute of Animal Pathology for preparation of the histological sections and Ursula Forster ( $(1)$ for assisting and partly performing the immunohistochemistry and PCR.

\section{LITERATURE CITED}

Adams A, Richards RH, De Mateo M (1992) Development of monoclonal antibodies to $\mathrm{PK}^{\prime} \mathrm{X}^{\prime}$, the causative agent of proliferative kidney disease. J Fish Dis 15:515-521

Anderson CL, Canning EU, Okamura B (1999) 18S rDNA sequences indicate that PKX organism parasitizes bryozoa. Bull Eur Assoc Fish Pathol 19:94-97

Bettge K, Wahli T, Segner H, Schmidt-Posthaus H (2009) Proliferative kidney disease in rainbow trout: time- and temperature-related renal pathology and parasite distribution. Dis Aquat Org 83:67-76

> Canning EU, Curry A, Feist SW, Longshaw M, Okamura B (2000) A new class and order of myxozoans to accommodate parasites of bryozoans with ultrastructural observations on Tetracapsula bryosalmonae (PKX organism). J Eukaryot Microbiol 47:456-468

> Clifton-Hadley RS, Bucke D, Richards RH (1987) A study of the sequential clinical and pathological changes during proliferative kidney disease in rainbow trout, Salmo gairdneri Richardson. J Fish Dis 10:335-352

> Diep CQ, Ma D, Deo RC, Holm TM and others (2011) Identification of adult nephron progenitors capable of kidney regeneration in zebrafish. Nature 470:95-100

Eissa AE, Zaki MM, Aziz AA (2010) Flavobacterium columnare/Myxobolus tilapiae concurrent infection in the earthen pond reared Nile tilapia (Oreochromis niloticus) during the early summer. Interdisciplinary Bio Central 2:5.1

El-Matbouli M, Hoffman RW (1994) Proliferative kidney disease (PKD) as an important myxosporean infection in salmonid fish. In: Pike AW, Lewis JW (eds) Parasitic diseases of fish. Samara Publishing Limited, Tresaith, p 3-15

Feist SW, Bucke D (1993) Proliferative kidney disease in wild salmonids. Fish Res 17:51-58
Feist SW, Longshaw M, Canning EU, Okamura B (2001) Induction of proliferative kidney disease (PKD) in rainbow trout Oncorhynchus mykiss via the bryozoan Fredericella sultana infected with Tetracapsula bryosalmonae. Dis Aquat Org 45:61-68

Ferguson HW (1981) Effects of temperature on the development of proliferative kidney disease in rainbow trout, Salmo gairdneri Richardson. J Fish Dis 4:175-177

> Grabner DS, El-Matbouli M (2008) Transmission of Tetracapsuloides bryosalmonae (Myxozoa: Malacosporea) to Fredericella sultana (Bryozoa: Phylactolaemata) by various fish species. Dis Aquat Org 79:133-139

> Hedrick RP, MacConnell E, de Kinkelin P (1993) Proliferative kidney disease of salmonid fish. Annu Rev Fish Dis 3: 277-290

Hedrick RP, Adkinson MA, MacConnell E (1998) Whirling disease: re-emergence among wild trout. Immunol Rev 166:365-376

Hintze J (2006) NCSS, PASS, and GESS. NCSS, Kaysville, UT. Available at www.ncss.com, released: 19 May 2006

Johnson PT, Paull SH (2011) The ecology and emergence of diseases in fresh waters. Freshw Biol 56:638-657

Karvonen A, Rintamäki P, Jokela J, Valtonen ET (2010) Increasing water temperature and disease risks in aquatic systems: climate change increases the risk of some, but not all, diseases. Int $\mathrm{J}$ Parasitol 40: 1483-1488

> Kent ML, Hedrick RP (1985) Development of the PKX myxosporean in rainbow trout Salmo gairdneri. Dis Aquat Org 1:169-182

Kent ML, Khattra J, Hervio DML, Devlin RH (1998) Ribosomal DNA sequence analysis of isolates of the PKX myxosporean and their relationship to members of the genus Sphaerospora. J Aquat Anim Health 10:12-21

> Koubková B, Baruš V, Prokeš M, Dyková I (2004) Raphidascaris acus (Bloch, 1779) larvae infections of the stone loach, Barbatula barbatula (L.), from the River Haná, Czech Republic. J Fish Dis 27:65-71

Longshaw M, Feist SW, Canning EU, Okamura B (1999) First identification of PKX in bryozoans from the United Kingdom-Molecular evidence. Bull Eur Assoc Fish Pathol 19:146-148

- Longshaw M, Le Deuff RM, Harris AF, Feist SW (2002) Development of proliferative kidney disease in rainbow trout, Oncorhynchus mykiss (Walbaum), following shortterm exposure to Tetracapsula bryosalmonae infected bryozoans. J Fish Dis 25:443-449

Moravec F (1970a) Studies on the development of Raphidascaris acus (Bloch, 1779) (Nematoda: Heterocheilidae). Acta Soc Zool Bohem 34:33-49

- Moravec F (1970b) On the life history of the nematode Raphidascaris acus (Bloch, 1779) in the natural environment of the river Bystrice, Czechoslovakia. J Fish Biol 2: 313-322

Moravec F (1979) Occurrence of the endoparasitic helminths in pike (Esox lucius L.) from the Mácha lake fishpond system. Acta Soc Zool Bohem 43:174-193

> Moravec F (1996) The amphipod Gammarus fossarum as a natural true intermediate host of the nematode Raphidascaris acus. J Parasitol 82:668-669

Moravec F (2004) Observations on the transmission and seasonality of infection of the nematode Raphidascaris acus in Salmo trutta fario in a small trout stream in North Bohemia, Czech Republic. Helminthologia 41: 91-97 
Morris DJ, Adams A (2006) Transmission of Tetracapsuloides bryosalmonae (Myxozoa: Malacosporea), the causative organism of salmonid proliferative kidney disease, to the freshwater bryozoan Fredericella sultana. Parasitology 133:701-709

Morris DC, Morris DJ, Adams A (2002) Development of improved PCR to prevent false positives and false negatives in the detection of Tetracapsula bryosalmonae, the causative agent of proliferative kidney disease. J Fish Dis 25:483-490

Okamura B, Anderson CL, Longshaw M, Feist SW, Canning EU (2001) Patterns of occurrence and 18S rDNA sequence variation of PKX (Tetracapsula bryosalmonae), the causative agent of salmonid proliferative kidney disease. J Parasitol 87:379-385

Okamura B, Hartikainen H, Schmidt-Posthaus H, Wahli T (2011) Life cycle complexity, environmental change and the emerging status of salmonid proliferative kidney disease. Freshw Biol 56:735-753

Reimschuessel R (2001) A fish model of renal regeneration and development. ILAR J 42:285-291

Reimschuessel R, Bennett RO, May EB, Lipsky MM (1990) Development of newly formed nephrons in the goldfish kidney following hexachlorobutadiene-induced nephrotoxicity. Toxicol Pathol 18:32-38

Reimschuessel R, Chamie SJ, Kinnel M (1996) Evaluation of gentamicin-induced nephrotoxicosis in toadfish. J Am Vet Med Assoc 209:137-139

Salice CJ, Rokous JS, Kane AS, Reimschuessel R (2001) New nephron development in goldfish (Carassius auratus) kidneys following repeated gentamicin-induced nephrotoxicosis. Comp Med 51:56-59

Editorial responsibility: Dieter Steinhagen,

Hannover, Germany
Schmidt-Posthaus H, Bettge K, Forster U, Segner H, Wahli T (2012) Kidney pathology and parasite intensity in rainbow trout Oncorhynchus mykiss surviving proliferative kidney disease: time course and influence of temperature. Dis Aquat Org 97:207-218

Sitjà-Bobadilla A (2008) Fish immune response to myxozoan parasites. Parasite 15:420-425

Sitjà-Bobadilla A, Palenzuela $\mathrm{O}$, Riaza A, Macías MA, Alvarez-Pellitero P (2007) Protective acquired immunity to Enteromyxum scophthalmi (Myxozoa) is related to specific antibodies in Psetta maxima (L.) (Teleostei). Scand J Immunol 66:26-34

Smith JD (1984) Development of Raphidascaris acus (Nematoda, Anisakidae) in paratenic, intermediate, and definitive hosts. Can J Zool 62:1378-1386

Valtonen ET, Haaparanta A, Hoffmann RW (1994) Occurrence and histological response of Raphidascaris acus (Nematoda: Ascaridoidea) in roach from four lakes differing in water quality. Int J Parasitol 24:197-206

Wahli T, Bernet D, Segner H, Schmidt-Posthaus H (2008) Role of altitude and water temperature as regulating factors for the geographical distribution of Tetracapsuloides bryosalmonae infected fish in Switzerland. J Fish Biol 73: 2184-2197

> Watanabe N, Kato M, Suzuki N, Inoue C and others (2009) Kidney regeneration through nephron neogenesis in medaka. Dev Growth Differ 51:135-143

> Zeidner NS, Dolan MC, Massung R, Piesman J, Fish D (2000) Coinfection with Borrelia burgdorferi and the agent of human granulocytic ehrlichiosis suppresses IL-2 and IFN $\gamma$ production and promotes an IL-4 response in C3H/HeJ mice. Parasite Immunol 22:581-588

Submitted: August 6, 2012; Accepted: January 24, 2013

Proofs received from author(s): March 19, 2013 